\title{
MEDIA KREATIF WALISONGO DALAM MENYEMAI SIKAP TOLERANSI ANTAR UMAT BERAGAMA DI JAWA
}

\author{
Failasuf Fadli \\ failasuffadli@gmail.com \\ Institut Agama Islam Negeri Pekalongan Jawa Tengah, Indonesia
}

\begin{abstract}
The purpose of this study is to find theoretical formulations about creative media through the study of Walisongo's creative works in the form of traditional wayang cultural arts and media, documents of cultural works in the field of architecture and Walisongo's historical documents in the context of tolerance. the specific purpose of this study was to find a Walisongo tolerance planting model towards people in Java. Considering that in Java in particular and in Indonesia in general, the complexities of the community, both in terms of language, culture, religion, etc. So it is prone to conflicts that occur in religious communities, because of a misunderstanding or lack of religious awareness that causes a lot of conflict between religious communities. This study uses a critical analysis method of manuscripts and objects of study about Walisongo's work. The results of this study can be concluded that the Javanese people in the Walisongo era with wayang and mosque media can live harmoniously between one tribe and another, can live peacefully between one religion with another religion, respect each other and not make heartache to fellow creatures of God.
\end{abstract}

Keywords: Media, Creative, Tolerance, Walisongo

\begin{abstract}
Abstrak
Tujuan Penelitian ini adalah menemukan rumusan teoritik mengenai media kreatif melalui kajian karya-karya kreatif Walisongo yang berupa media seni budaya tradisional wayang, dokumen hasil karya budaya dalam bidang arsitektur dan dokumen sejarah Walisongo dalam kontek toleransi. tujuan khusus penelitian ini adalah untuk menemukan model penanaman toleransi Walisongo terhadap masyarakat di Jawa. Mengingat di Pulau Jawa khususnya dan di Indonesia pada umumnya, corak masyarakatnya yang majemuk, baik dari sisi bahasa, budaya, agama, dll. Sehingga rawan terjadi konflik yang terjadi pada masyarakat beragama, karena adanya kesalahpahaman atau kurangnya kesadaran beragama sehingga menyebabkan banyak terjadi konflik antar umat beragama. Penelitian ini menggunakan metode analisis kritis terhadap naskah naskah dan objek kajian tentang karya Walisongo. Hasil penelitian ini dapat disimpulkan bahwa masyarakat Jawa pada zaman Walisongo dengan media wayang dan masjid dapat hidup rukun antara satu suku dengan yang lainnya, dapat hidup damai antara satu gama dengan agama lainnya, saling menghormati dan tidak membuat sakit hati kepada sesama makhluk Tuhan.
\end{abstract}

Kata Kunci: Media, Kreatif, Toleransi, Walisongo 


\section{PENDAHULUAN}

Tren konflik yang terjadi akhir-kahir ini sungguh sangat mengkhawatirkan dan mengancam kebhinekaan Negara Kesatuan Republik Indonesia. konflik yang terjadi pada masyarakat beragama selama ini karena adanya kesalahpahaman atau kurangnya kesadaran beragama sehingga menyebabkan banyak terjadi konflik antar umat beragama. Sejak 3 tahun terakhir di Indonesia terdapat beberapa kejadian intoleransi antar umat beragama, data dari Ringkasan Eksekutif Laporan Kebebasan Beragama dan Berkeyakinan Komisi Nasional Hak Asasi Manusia menyebutkan bahwa pada tahun 2014, Komnas HAM mencatat ada 74 kasus intoleransi yang dilaporkan ke pos pengaduan desk Kebebabasan Beragama dan Berkeyakinan (KBB), pada periode tahun berikutnya ada 87 kasus pengaduan, pada tahun 2016 terjadi peningkatan sampai dengan 100 kasus aduan intoleransi. Konflik terbaru, yakni rangkaian teror bom yang terjadi menjelang bulan Ramadhan atau bulan Mei 2018 yang terjadi di sejumlah titik di Jawa Timur diantaranya menyasar 3 Gereja di Kota Surabaya yang menelan korban sebanyak 18 orang.

Adanya kasus-kasus intoleransi di Indonesia yang disebutkan diatas sungguh sangat memprihatinkan. Kejadian yang dilakukan oleh segilintir orang tersebut telah berdampak besar, apalagi kalau dilihat dari kacamata dunia internasional, sungguh disayangkan ada sebagian masyarakat Indonesia yang mengatasnamakan Islam melakukan kejahatan intoleransi. Hasil penelitian muhaemin menyatakan bahwa intoleransi akan sangat berbahaya, menciderai nilai-nilai keberagamaan dan harmoni antar umat beragama dan juga akan mengancam keutuhan Negara Kesatuan Republik Indonesia yang berlandaskan Pancasila dan Undang-Undang Dasar 1945 (Muhaeimin, 2019, 32). Hal ini juga melunturkan adat-adat orang timur yang dipandang dunia internasional bahwa orang Indonesia berkepribadian ramah, bersahabat, tepa selira, toleransi, gotong royong, saling menolong, dll. Identitas orang ketimuran ini telah merekat di masyarakat Indonesia sejak dulu dan tidak dibatasi oleh Suku, Agama, Ras dan Adat. Indonesia yang sebagian besar masyarakatnya beragama Islam, identitas ketimuran tersebut tidak terlepas dari Founding Father Islam yang telah menanamkan kepribadian yang baik kepada masyarakat yang dalam hal ini adalah Walisongo. Hal ini 
sejalan dengan penelitian yang dilakukan Qodir yang menyatakan bahwa Elit agama hendaknya harus memberikan contoh yang nyata dalam ucapan maupun tindakan dengan sikap yang santun, bijaksana, damai, dan menentramkan (Qodir, 2016:435)

Sebagian besar masyarakat Jawa menilai keberhasilan dakwah Walisongo dari sudut pandang mistik. Yakni faktor tingginya ilmu kanuragan, kesaktian, jaya kawijayan (Saksono, 1996:109), sebagai faktor yang dianggap menjadi kunci keberhasilan dakwah Walisongo. Meskipun bisa jadi asumsi ini benar, namun dalam wilayah akademis, tentu pandangan mistik ini tidak dapat dipertanggungjawabkan kebenarannya. Karenanya, berbagai upaya ilmiah untuk meneliti dan menelusuri jejak dakwah Walisongo hingga mendapat keberhasilan yang begitu gemilang akan selalu menarik untuk dilakukan. Sebelum Walisongo datang ke tanah nusantara, agama HinduBudha sudah berabad-abad menjadi agama masyarakat nusantara. Dengan datangnya Walisongo di tanah nusantara khususnya Jawa dengan misi utama menyebarkan Islam, ternyata metode penyebarannya unik. Metode penyebaran agama Islam tidak menggunakan jalur kekerasan atau perang seperti yang ada di Timur Tengah, namun melalui pendekatan yang humanis. Hal yang pertama dilakukan Walisongo adalah memahami sosail budaya masyarakat Jawa. Walisongo membaur dengan masyarakat yang kala itu sebagian besar masih beragama Hindu Budha. Setelah tatanan sosial masyarakat dipahami, kemudian Walisongo mencari cara bagaimana caranya agar masyarakat dapat menerima agama Islam dengan ikhlas tanpa kekecewaan, tanpa menyimpan rasa dendam kepada penyebar agama Islam. Kalaupun ada masyarakat yang tidak mau menerima Islam sebagai agamanya, orang tersebut tetap baik terhadap orang yang masuk agama Islam. Agama merupakan hal yang fundamental bagi pribadi seorang manusia. Jika misi Walisongo tidak hati-hati dalam menyebarkan agama Islam, maka hasilnya justru masyarakat Hindu budha berbalik menyerang atau memeranginya, karena merasa terusik dengan adanya agama baru yang datang. Peran Walisongo dalam menyebarkan agama islam secara damai, tidak terlepas dari nilai-nilai toleransi yang dijunjung tinggi. Walisongo menyemai sikap-sikap toleransi masyarakat dengan media kreatif yang dapat diterima oleh masyarakat. 
Berkaitan dengan kreatifitas pendidikan Walisongo, salah satu contoh konkrit bentuk kreatifitas pendidikan Walisongo adalah inisiatif yang dilakukan oleh Sunan Kalijaga dalam menggunakan Wayang sebagai media dakwah. Pada awalnya, Wayang dianggap haram karena berbentuk gambar yang menyerupai manusia. Dengan kreatif, Sunan Kalijaga merubah bentuk Wayang dengan memodifikasinya agar tidak persis menyerupai manusia, seperti ukuran tangan yang lebih panjang dari ukuran kaki, kepalanya dibuat menyerupai binatang agar tidak serupa dengan manusia. Usulan Walisongo tersebut diterima oleh dewan Wali, yang akhirnya mendukung strategi pendidikan Sunan Kalijaga yang menggunakan pendekatan Seni Budaya, salah satunya adalah dengan seni pertunjukan Wayang yang alur ceritanya dimasukkan pokok-pokok akidah. Tidak hanya mendukung, Dewan Wali juga menciptakan gamelannya. Peristiwa itu kira-kira terjadi pada tahun 1443 M (Yunus, 2013). Contoh kreatifitas lain dilakukan oleh Sunan Kudus. Melalui pemahamannya mengenai budaya masyarakat Jawa yang masih kental dengan sistem kepercayaan Hindu - Budha, Sunan Kudus berusaha mendekati masyarakat dari sudut pandang masyarakat itu sendiri. Dikisahkan, Sunan Kudus pernah menghias seekor lembu dan mengikatnya di halaman masjid. Masyarakat yang masih memuliakan lembu sebagai konsekwensi ajaran Hindu - Budha yang mereka anut datang berduyun-duyun menyaksikan lembu itu. Sunan Kudus memanfaatkan momen tersebut untuk melancarkan aksi dakwah dan pendidikan masyarakatnya. Kreatifitas yang dilakukan Sunan Kudus ini mendapat simpati masyarakat, sehingga dakwahnya perlahan diterima oleh masyarakat (Fatkhan, 2003:125).

Selain itu, cara-cara kreatif juga banyak dilakukan oleh Wali-wali yang lain. Misalnya saja Sunan Giri dengan keahliannya dalam bidang tata negara meciptakan pola tata Istana, protokoler kerajaan di desain sedemikian rupa hingga memuat unsurunsur ajaran islam, merubah sistem perhitungan bulan, tahun, windu, masa dan mulai menggunakan kertas sebagai alat tulis menulis. Sunan Bonang keahliannya dalam bidang musik, kemudian mengkreasi peralatan musik yang mengiringi wayang seperti gamelan, lagu dan nyayian. Sunan Drajat mendesain bentuk rumah dan alat angkutan yang ramah dengan budaya lokal, namun syarat akan ajaran Islam. Sunan Gresik 
menggunakan kemampuan seninya dalam mengkreasi pola dan motif batik, lurik dan perlengkapan kuda (Fatkhan, 2003:126). Walisongo juga banyak memprakasai pembangunan Masjid dengan memadukan desain arsitektur Hindu, Budha, Cina bahkan Eropa. Media-media kreatif yang di ciptakan Walisongo tidak lain untuk menghormati budaya-budaya lokal yang sudah ada sejak dulu, sehingga menghasilkan sikap toleransi di lingkungan masyarakat. Mengingat pentingnya nilai-nilai toleransi beragama di kalangan masyarakat yang majemuk, sehingga, sehingga perlu di eksplore lebih jauh bagaimana walisongo dalam mengkreasi dan memodifikasi karya-karyanya yang mana digunakan sebagai media menebarkan nilai-nilai toleransi kepada masyarakat di pulau Jawa.

\section{METODE PENELITIAN}

Dalam penelitian ini, penulis mencoba mengkolaborasikan antara penelitian pustaka dan melakukan observasi di lapangan, karena yang diteliti tidak hanya berupa kalimat atau teks, namun juga seni budaya hasil warisan Walisongo. Penelitian pustaka dilakukan dengan menelusuri karya-karya tentang Wayang pada zamannya. Hasil penelitian terdahulu mengenai rekam jejak Walisongo di nusantara, terutama kaitannya dengan model media yang digunakan dalam menanamkan sikap toleransi. Penelitian lapangan dilakukan dengan menelusuri berbagai Peninggalan Walisongo dalam bidang media seni budaya tradisional yang memiliki dimensi kreatif meliputi, bangunan/arsitektur dan wayang yang sekaligus sebagai sumber data primer dalam penelitian ini. Sedangkan sumber sekundernya berupa tulisan/catatan hasil karya pakar Walisongo yang meliputi data-data pustaka berupa buku-buku, majalah, dokumen, catatan, dan kisah-kisah sejarah Walisongo. Dimensi sejarah dalam penelitian ini mengakomodir ruang agama, sehingga selain mengumpulkan data-data media kreatif yang dimiliki Walisongo juga menyesuaikan dengan alur perjalanan penyebaran agama Islam di nusantara. Teknik analisis dalam penelitian ini melalui bebrapa tahap. Tahap yang pertama pada saat pengumpulan data, sinkronisasi berbagai sumber. Kevalidan dan keabsahan sumber yang autentik menjadi prioritas. Inti dari fokus penelitian di uraikan hingga menjadi diskripsi yang dapat dipertanggungjawabkan nilai keabsahannya. Pada analisis tahap berikutnya yaitu hasil uraian diskripsi di telaah kembali, dianalisis, 
dihubungkan antara satu bagian dengan bagian lain yang sequen secara data. Pada akhirnya dihasilkan suatu simpulan yang menjawab permasalahan dalam penelitian ini.

\section{HASIL PENELITIAN DAN PEMBAHASAN}

Wayang dan masjid merupakan dua dari sekian banyak hasil karya kreatif Walisongo di pulau Jawa. Wayang sendiri tidak seratus persen hasil karya Walisongo, karena sebelum Islam masuk ke Jawa, wayang sudah ada sejak zaman kerajaan Hindu Budha. Wayang merupakan budaya adiluhung masyarakat Jawa sejak zaman dahulu. Wayang sebelum Walisongo berbentuk seperti manusia. Ketika kerajaan Majapahit runtuh, sebagian peninggalan seni-budaya istana yang berupa perlengkapan upacara kerajaan dibawa ke kesultanan Demak termasuk wayang dan alat gamelan yang merupakan seni budaya istana yang sudah berkembang pada zaman Hindu-Budha. Ketika wayang diadopsi Demak, kemudian Raden Fatah selaku Sultan Demak tidak serta merta digunakan begitu saja. Raden Fatah meminta Walisongo meyempurnakan bentuk wayang dan membuat lakon carangan yang didalamnya termuat atau mencerminkan hal-hal pokok ajaran Islam yakni rukun Islam.

Dengan adanya perintah dari Raden Fatah, maka Sunan Kalijaga dengan senang hati melaksanakan perintah Raden fatah. Sunan Kalijaga merupakan salah satu Walisongo yang memiliki jiwa seni, tidak lain karena Sunan Kalijaga adalah pribumi Jawa dan sejak muda sudah menyenangi seni dan budaya. Sunan Kalijaga memasukan unsur Aqidah, akhlak bahkan ibadah. Wayang yang sebelumnya menyerupai wujud manusia, didesain ulang agar tidak menyerupai manusia. Kepala yang terdiri hidung, mata, mulut didesain sedemikian rupa hingga tidak menyerupai kepala manusia. Begitu juga badan wayang yang didesain tidak ideal dengan wujud asli manusia. Bahkan Tangan dan kaki sangat jauh dari penggambaran manusia. Hal ini disebabkan dalam ajaran Islam ada larangan penggambaran yang menyerupai bentuk wujud manusia. Hasil desain ulang wayang dapat dilihat sampai dengan sekarang ini.

Selain bentuk wayang yang didesain ulang, Jumlah wayang juga mengalami penambahan, yakni ada istilah Pandawa lima. Wayang yang berjumlah lima ini, tidak lain ingin menyampaikan muatan unsusr Aqidah, yakni rukun Islam yang jumlahnya 
ada lima. Rukun Islam dijelmakan dalam tokoh-tokoh wayang. Rukun Islam yang pertama Syahadat diwujudkan dalam tokoh Puntadewa. Sunan Kalijaga memodifikasi "Jimat kali maha usada" semboyan yang sudah ada sejak zaman Hindu-Budha menjadi "Jimat Kalimo Sodho" yang berarti "Azimat Kalimat Syahadat". Jimat merupakan simbol dari sebuah kunci kesuksesan kehidupan. Jadi manusia yang ingin selamat dunia akhirat harus mempunyai jimat tersebut. Yakni dengan melafalkan Syahadatain yang secara harfiah berarti bersaksi mengakui Allah SWT sebagai Tuhan dan Muhammad sebagai Nabi. Allah SWT memiliki Asma al husna, sedangkan nabi Muhammad memiliki sifat-sifat yang mulia. Sunan Kalijaga mengejawantahkan beberapa Asma al husna dan sifat nabi dalam tokoh Puntadewa yang digambarkan seorang raja yang berbudi luhur, arif bijaksana, adil, jujur, dapat dipercaya, dan mengayomi rakyatnya.

Personifikasi rukun Islam yang kedua adalah tokoh Werkudara atau Bima. Bima digambarkan tokoh wayang yang kuat, gagah perkasa, yang terkenal sakti, suka mengakkan keadilan, menjunjung tinggi nilai-nilai kebaikan. Bima juga digambarkan sebagai penegak pandawa, karena Bima jarang sekali duduk, bahkan tidurpun dengan berdiri. Hal ini sesuai kaidah Shalat. Shalat merupakan tiang agama, harus kuat melaksanakannya sehari lima kali. Shalat wajib lima kali merupakan ibadah yang sangat berat bagi sebagian muslim, maka dari itu perlu kekuatan yang harus dimiliki setiap muslim baik dhahir maupun batin dalam menjalakankan ibadah Shalat.

Rukun Islam ketiga adalah puasa diwujudkan pada tokoh Janaka atau Arjuna. Puasa pada dasarnya bertujuan ingin membersihkan diri agar hati atau batin menjadi suci, bersih, jernih. Dengan berpuasa diharapkan jiwanya menjadi kuat menghadapi segala cobaan sehingga menghasilkan hati/batin yang bersih dan mudah untuk mendekat kepada Allah SWT. Arjuna merupakan laki-laki pilihan atau lelananging jagat. Kejernihan Arjuna memancar dari aura wajah dan tubuhnya. Selain itu Arjuna merupakan tokoh wayang yang perasaannya halus, sangat enggan menolak suatu kebaikan, sehinga seolah-olah Arjuna lemah, padahal Arjuna tidak ingin menyakiti hati orang lain. Kesenian dan keindahan merupakan elemen yang sudah terpatri di jiwa sanubari Arjuna. 
Zakat dan Haji secara berurutan menempati posisi rukun keempat dan kelima dipresntasekan tokoh wayang kembar yang bernama Nakula-Sadewa. Karakter Nakula saling melengkapi. Berkepribadian bagus, berpakaian sopan, mempunyai perilaku pekerja keras, berkecukupan, dan dermawan. Dalam penjelasan akal logis, orang yang gemar bekerja, akan mendapatkan harta benda yang kemudian mampu menunaikan ibadah Haji dan tidak lupa untuk membersihkan harta benda agar suci lahir dan batin, maka orang ersebut mengeluarkan Zakat (Anggoro, 2018:129).

Selain Wayang, Walisongo juga meninggalkan warisan fisik dalam bentuk bangunan berupa masjid. Peninggalan-peninggalan masjid Walisongo diantaranya masih dapat kita lihat sampai dengan sekarang, walaupun sebagian sudah ada yang di renovasi maupun rehabilitasi. Diantara Masjid peninggalan Walisongo adalah Masjid Menara Kudus. Batu pertama pembangunan Masjid ini berasal dari Baitul Maqdis. Desain arsitektur Masjid Menara Kudus menggunakan arsitektur bangunan agama Hindu-budha. Bentuk menara menyerupai candi peninggalan kerajaan Hindu-Budha yang ada di Jawa (Supatmo, 2017:110). Selain Masjid Menara Kudus, Masjid Agung Demak berlokasi di Jawa Tengah. Desain arsitektur masjid Demak menggunakan arsitektur Jawa, atap masjid berupa limas bersusun tiga yang ditopang delapan tiang(Suparjo, 2008:176). Di sisi barat Pulau Jawa terdapat Masjid Agung Banten yang menara kubahnya bertumpuk limasan menyerupai Pagoda China. Masjid Agung Banten memadukan desain arsitektur Hindu, Cina, dan Eropa (Laksmi, 2017:366-367). Masih di sisi barat pulau Jawa, disekitar Cirebon, terdapat masjid Sang Cipta Rasa, Masjid ini peninggalan Sunan Gunung Jati. Desain arsitektur masjid Sang Cipta Rasa adalah perpaduan gaya Hindu dan Islam, atap masjid berbentuk limasan bersusun tiga (Alamsyah, 2010:177).

\section{Wayang kulit dan Masjid Sebagai Wahana Menanam Toleransi Antar Umat Beragama}

Walisongo dalam membangun tatanan sosial menggunakan cara-cara yang unik. Banyak Ide-ide Walisongo tidak hanya berdasar syariat agama Islam saja, namun berkolaborasi dengan sosial seni budaya di Pulau Jawa yang notabene mayoritas masyarakatnya beragama Hindu-Budha. Ide kreatif Walisongo dalam menyebarkan 
agama Islam tidak lain adalah mencari media yang dapat diterima masyarakat Jawa pada waktu itu. Media yang di senangi masyarakat Jawa. Secara kultural, masyarakat Jawa sangat menyukai simbol-simbol kehidupan. Simbol yang mempunyai nilai-nilai filosofis kehidupan bermasyarakat. Masyarakat Pulau Jawa yang heterogen, majemuk dalam berbagai bidang, baik agama, ideologi, budaya, memerlukan suatu media yang dapat menyatukan keberagaman tersebut.

Walisongo menciptakan suatu gagasan-gagasan baru dalam seni Wayang, walaupun sebelumnya wayang sudah ada, namun ide kreatif Walisongo khususnya Sunan kalijaga merupakan prestasi yang sangat monumental. Wayang beber sejak zaman raja Airlangga di desain ulang oleh Sunan Kalijaga, sehingga Terciptalah Wayang kulit versi Sunan Kalijaga dengan memasukkan unsur ajaran Islam (Anggoro, 2018:128). Cerita-cerita baru dikembangkan oleh Sunan Kalijaga dengan mengkolaborasikan Teologi maupun syariat Islam. Media wayang, oleh Sunan kalijaga dikembangkan sebagai media yang digunakan dalam menanamkan nilai-nilai luhur budaya Jawa dan sekaligus nilai-nilai agama Islam. Toleransi dalam bahasa arab disebut "tasamuh" artinya bermurah hati, yaitu bermurah hati dalam pergaulan. Kata lain dari tasamuh ialah "tasahul" yang artinya bemudah mudahan (Ghufron, 199:132). Toleransi merupakan sasaran utama nilai yang ditanamkan Walisongo selain ajaran agama Islam. Toleransi dianggap penting karena masyarakat Jawa yang majemuk. Prediksi Walisongo dalam menanamkan nilai-nilai toleransi memang sudah tepat. Karena banyak perbedaan yang dimiliki masyarakat Indonesia pada umumnya dan Jawa pada khususnya.

\section{Wayang sebagai Sarana Membangun Konstruksi Toleransi}

Wayang sebagai Media kreatif yang diadopsi dari kebudayaan Hindu-budha oleh Walisong, kemudian digunakan sebagai media untuk mempererat tali persaudaraan dikalangan masyarakat Jawa, dengan tetap mengadopsi lakon atau cerita sebelumnya, namun sudah disisipi muatan ajaran Islam. Sebagaimana seperti cerita Mahabarata atau Ramayana yang notabene merupakan saduran dari kitan suci agama Hindu (Anggoro, 2018:127) di desain ulang dengan memasukan unsur-unsur ajaran Islam dengan tetap menggunakan plot cerita tersebut. Walisongo sebagai pendesain ulang Wayang tetap mempertahankan budaya Hindu. Sunan Kalijaga lebih mengutamakan menghormati 
kebudayaan Hindu, namun sedikit demi sedikit ajaran Islam dapat tersampaikan kepada msayarakat di Jawa. Nilai toleransi antar beragama sangat terlihat jelas antara Walisongo yang beragama Islam dengan masyarakat yang non Islam. Dengan pertunjukan wayang siapapun yang melihat atau menonton baik orang Islam maupun non Islam melebur menjadi satu.

Wayang sebagai pertunjukan purwarupa budaya Hindu tetap dilanjutkan oleh Walisongo, namun isi muatan bernuansa Islam. Hal ini terlihat dari penggunaan Instrumen Hindu yang tetap digunakan namun muatan isinya berbeda adalah tentang reka ulang semboyan "Jimat Kalima Shada" Pada prinsipnya, kalimat tersebut instrument telogi Hindu yang berarti "jimat kali maha usada" namun oleh Walisongo kalimat ini didesain menjadi "azimah kalimat syahadah" (Suparjo, 2008:181). Frase yang terakhir merupakan pernyataan seseorang tentang keyakinan bahwa tiada Tuhan selain Allah, dan bahwa Muhammad adalah utusan Allah. Keyakinan tersebut merupakan spirit hidup dan penyelamat kehidupan bagi setiap orang. Hal itu menjelaskan bahwa Walisongo walaupun mempunyai misi untuk mendakwahkan Islam, namun tetap menghormati budaya-budaya Islam dengan cara tetap memakai istilahistilah budaya Hindu, namun muatannya diganti dengan ajaran Islam.

Walisongo juga menggunakan kesenian wayang dalam merekonstruksi tatanan sosial masyarakat Jawa, yang sebelumnya sering terjadi peperangan diantara satu kerajaan Hindu dengan kerajaan Hindu lain ataupun kerjaan budha, sering terjadi keributan sosial. Dengan seni pertunjukan wayang, Walisongo membangun masyarakat yang beradab dan berbudaya. Untuk membangun arah yang berbeda dari pakem asli pewayangan, Walisongo menambahkan dalam cerita pakem pewayangan dengan plot yang berisi visi sosial kemasyarakat Islam (Suparjo, 2008:181), yang didalamnya terdapat muatan saling menghormati antar sesama, walaupun berbeda bahasa, budaya, suku, bahkan agama. Sejak dahulu masyakarakat pulau Jawa cenderung majemuk. Selain agama Hindu, Budha, Cinapun sudah ada sejak zaman kerajaan Hindu-Budha. Sehingga nilai-nilai toleransi antar umat beragama sudah di tanamkan Walisongo kepada masyarakat di Pulau jawa. Figur-figur tokoh dalam pewayanganpun dikembangkan oleh Walisongo dalam menyemai sikap toleransi masyarakat di Pulau 
jawa. Diantaranya, selain Pandawa lima, juga ada figur punakawan (Semar, Nala Gareng, Petruk, dan Bagong). Karakteristik figure pewayangan tersbut mencerminkan representasi dari orang yang supel, tidak egois, dan berkepribadian.

\section{Arsitektur Masjid sebagai Representasi Toleransi Antar Umat Beragama}

Walisongo sangat ramah dalam penggunaan simbol-simbol budaya Hindu,Budha, Cina, Eropa di dalam seni arsitektur Masjid. Hal ini terbukti beberapa arsitektur Masjid peninggalan Walisongo hampir sebagian besar akulturasi arsitektur budaya lain. Walisongo tidak anti terhadap penggunaan arsitektur agama selain Islam. Hal ini menunjukkan bahwa sikap toleransi Walisongo terhadap budaya agama selain Islam sangat baik. Toleransi dalam Islam, memberikan kemudahan bagi siapa saja untuk menjalankan apa yang ia mampu termasuk menjalankan apa yang diyakini sesuai dengan ajaran masing-masing tanpa ada tekanan dan tidak mengusik ketauhidan (Damanik, 2019:2). Walisongo tidak hanya sebatas dalam ucapan saja dalam hal toleransi. Bahkan konsep bangunan atap bersusun tiga yang notabene sebuah tradisi Hindu diadopsi Walisongo menjadi atap Masjid. Raden fatah selaku sultan pertama Demak menginnginkan bahwa Masjid didesain agar masyarakat dari berbagai kalangan dapat menggunakannya, karena agama Hindu-Budha erat sekali dengan kasta sosial, bahkan dalam urusan beribadahpun bangunannya dibedakan.

Tradisi Hindu yang sangat kental akan strata sosial, Berdampak pada perwujudan bangunan Pura. Susunan atap pura dengan jumlah tertentu menandakan siapa yang membangun, siapa yang memiliki, dan siapa yang menggunakan. Seorang raja besar (Raja yang mempunyai daerah taklukan) membangun pura dengan jumlah atap bersusun Sebelas dan yang berhak menggunakan Pura tersebut untuk beribadah adalah Raja dan kalangan bangsawan. Di kelas bawahnya adalah Pura beratap susun tujuh. Pura ini dibangun oleh raja dan penggunaanya masih sama dengan yang Pura beratap sebelas. Srata Pura setelah susun tujuh adalah Pura susun tiga yang biasanya dibangun oleh rakyat biasa dan digunakan sebagai tempat beribadah mereka. Pura susun tiga dapat juga dibangun oleh Raja yang kemudian untuk dipergunakan untuk rakyatnya. (Suparjo, 2008:181). Walisongo sengaja mendesain atap bersusun tiga agar secara filosofis baik rakyat jelata maupun bangsawan sama-sama menggunakan masjid 
tersebut. Sevara tidak langsung juga menghilangkan kasta sosial di dalam masjid. Desain atap bersusun tiga merupakan adopsi dari desain arsitektur bangunan Pura. Model atap Masjid bersusun tiga tidak ditemukan di negara timur tengah. Hal ini menandakan bahwa Walisongo sangat menghargai nilai-nilai budaya lokal. Ide persamaan harkat yang diprakarsai Raden Patah, kemudian di implementasikan Walisongo dalam penyamaan atap Masjid dengan atap susun tiga yang secara tidak langsung mengartikan menghapus system kasta pada masyarakat Hindu pada waktu itu. Simbolisasi atap masjid bersusun tiga ternyata berhasil diterapkan. Kalangan bangsawan dan rakyat biasa yang sudah menganut agama Islam bersedia menggunakannya secara bersama-sama.

Desain lain yang diadopsi Walisongo dalam seni arsitektur Masjid adalah desain arsitektur menara. Masjid peninggalan Walisongo yang terletak di Kudus mempunyai menara yang unik. Menara Masjid Kudus berbentuk menyerupai candi Hindu-Budha. Hal ini terlihat dari bangunan batu bata yang bertumpuk-tumpuk persegi empat yang menjulang tinggi keatas. Dinding menara terdapat relief budaya Hindu (Supatmo, 2017:110). Masjid Menara kudus merupakan saksi bisu nilai-nilai toleransi yang disemai oleh Walisongo khusunya Sunan Kudus. Desain Masjid menara Kudus yang berbentuk menyerupai candi, secara tersirat merupakan perwujudan tepa selira atau tenggang rasa antar umat beragama. Sunan Kudus mampu membumikan ajaran Islam melalui Masjid. Sunan Kudus lebih mengutamakan kearifan lokal dalam mendakwahkan ajaran Islam, sehingga dapat menyesuaikan dengan kebudayaan HinduBuhda dengan cara membaur dengan masyarakat melalui pendekatan budaya, sehingga tercipta suasana saling hormat menghormati diantara masyarakat Kudus. Sunan Kudus melarang masyarakat Islam untuk menyembelih Sapi, karena Sunan Kudus mengetahui bahwa sapi merupakan hewan suci bagi orang Hindu. Sunan Kudus tidak ingin menyakiti atau membuat marah orang Hindu dengan menyembelih Sapi. Masyarakat Islampun di Kudus mengikuti pesan Sunan Kudus untuk tidak menyembelih sapi.

Masjid Sang Cipta Rasa juga memiliki kesamaan dengan Masjid lain peninggalan Walisongo. Masjid yang dibangun atas prakarsa Sunan Gunung Jati ini memadukan budaya Hindu dan Islam. Hal itu terlihat dari atap bangunan limas 
bersusun, desain dinding mirip seperti candi (Alamsyah, 2010:177). Dalam filsafat Budha, candi yang terdiri dari tiga lantai merepresentasikan filsafat perjalanan ruh manusia. Lantai pertama sebagai representasi alam sebelum manusia; lantai kedua sebagai representasi alam manusia; dan lantai ketiga sebagai representasi alam pasca melewati lingkaran karma. Adapun stupa merupakan representasi penyatuan ruh manusia dengan jiwa kosmik penggerak lingkaran karma. Masjid yang beratap tiga lapis dengan puncaknya diletakkan mustaka dapat dilihat sebagai adopsi dari candi Budha tersebut (Suparjo, 2008:180). Namun oleh Walisongo diganti dengan unsur teologi Iman, Islam dan Ihsan. Susun atap yang pertama diartikan Iman yang terdiri dari enam rukun Iman. Susun atap yang kedua diartikan Islam, yang terdiri lima rukun dan atap yang paling puncak representasi dari Ihsan, yang mempunyai arti beribadah seakanakan melihat Allah, dan kalaupun tidak bisa melihat Allah maka kita yakin bahwa Allah melihat diri kita. Dengan adanya atap ihsan pada diri kita maka bisa selalu yakin bahwa stiap tingkah hidup selalu di awasi sehingga sudah seharusnya untuk selalu berbuat menjalankan perintah Allah serta menjauhi setiap laranganya. Hal ini menandakan bahwa Sunan Gunung Jati menghormati budaya Hindu yang sudah ada di tanah Cirebon. Kemudian pada perkembangannya Masjid Sang Cipta Rasa ada penambahan ornamen Masjid berupa porselin yang konon berasal dari Cina. Dengan demikian Desain Masjid Sang Cipta Rasa sangat ramah terhadap budaya selain Islam. Masyarakat secara tidak langsung dapat mengambil pelajaran apa arti sebuah nilai saling hormat menghormati diantara umat beragama. Dari beberapa masjid peninggalan Walisongo yang memadukan berbagai kebudayaan Hindu, Budha, China, dapat di artikan bahwa Walisongo lebih mementingkan esensi dari sebuah masjid, yakni sebagai sarana untuk beribadah. Inti ajaran Islam adalah pada dasarnya menyembah kepada Allah SWT yang kemudian dapat berlaku baik kepada sesama mahluk Tuhan Yang Maha Esa.

\section{SIMPULAN DAN SARAN}

Walisongo melakukan desain ulang bentuk wayang agar tidak menyerupai manusia asli. Selain itu Walisongo mengkreasi tokoh pewayangan baru, seperti Pandawa Lima dan Punakawan. Walisongo juga memasukkan ajaran Islam pada cerita 
atau carangan pada saat pertunjukan, namun tetap menggunakan alur/plot budaya Hindu Budha. Melalui media kreatif Wayang, Walisongo dapat menebarkan nilai-nilai toleransi masyarakat di Jawa sehingga tumbuh sikap toleransi antar umat beragama. Peninggalan Walisongo yang lain adalah Masjid. Walisongo menjadikan Masjid pusat peradaban sekaligus simbol toleransi umat beragama di Indonesia. Masjid sekaligus menjadi pusat asimilasi budaya, sehingga Masjid mampu merangkul segala semua elemen masyarakat, baik itu umat muslim maupun umat Hindu-Budha kala itu. Dari kedua hasil warisan Walisongo diatas sehingga tercipta suatu masyarakat yang dapat hidup rukun antara satu suku dengan yang lainnya, dapat hidup damai antara satu gama dengan agama lainnya, saling menghormati dan tidak membuat sakit hati kepada sesama makhluk Tuhan. Saran sebagai tindak lanjut dari penelitian ini sangat relevan dijadikan sumber informasi baik bagi akademisi maupun masyarakat awam, mengingat situasi dan kondisi masyarakat Islam pada era sekarang cenderung lemah dari nilai-nilai toleransi terhadap sesama saudara sebangsa dan senegara. Dalam penelitian ini masih terdapat banyak kekurangan, sehingga masih banyak yang dapat dikaji tentang khasanah keilmuan warisan Walisongo. Pada penelitian ini masih sebatas mengkaji dua objek hasil warisan seni budaya Walisongo yakni wayang dan masjid. Sehingga masih terbuka lebar peneliti lain untuk mengkaji objek lain, seperti sastra, alat musik, dll. 


\section{DAFTAR PUSTAKA}

A Mas'adi, Ghufron. (1999). Ensiklopedi Islam. Jakarta: Raja Grafindo Persada

Alamsyah, Suwardi. (2010). Nilai Budaya Arsitektur Masjid Sang Cipta Rasa Cirebon Provinsi Jawa Baat. Jurnal Pantjala Vol. 2. No. 2.

Al-Sam, Rizal Firdaus. (2000). Wayang sebagai media dakwah. Yogyakarta: Gama Media

Ambary, Hasan Mu'arif. (1998). Menemukan Peradaban Jejak Arkheologis \& Historis Islam Indonesia. Jakarta: Logos Wacana Ilmu.

Amir, Hazim. (1991). Nilai-Nilai etis dalam wayang. Jakarta:CV. Mulia Sari

Bastomi, Suwaji. (1996). Gemar Wayang. Semarang: IKIP Semarang Press.

Bleicher, Josef. (1980). Contemporary Hermeneutic as Method, Philosophy and Critique. London: Routledge.

Daliman, A. (2012). Islamisasi dan Perkembangan Kerajaan-kerajaan Islam di Indonesia. Yogyakarta: Ombak.

Damanik, Nurliana. (2019). Toleransi Dalam Islam. Jurnal Shahih:Jurnal Ilmu Kewahyuan. Vol. 2 No. 1.

Fatkhan, Muh. (2003). Dakwah Budaya Walisongo: Aplikasi Metode Dakwah Walisongo di Era Multikultural, Jurnal Aplikasia, Vol. IV, No. 2.

Haryono, S. (1998). Pratiwimba Adhiluhung, Sejarah dan perkembangan Wayang. Yogyakarta: Djambatan.

Kaelan. (2010). Metode Penelitian Agama Kualitatif Interdisipliner. Yogyakarta: Paradigma.

Kayam, Umar. (2001). Kelir Tanpa Batas. Yogyakarta: UGM.

Khotimah. (2013). Toleransi Beragama. Jurnal Ushuluddin Vol. XX No.2

Laksmi, Bintang Widya. (2017). Masjid Agung Banten: Perpaduan Tiga Budaya dalam satu Arsitektur. Prosiding Seminar Heritage Ikatan Peneliti Lingkungan Binaan Indonesia (ILPBI).

Magnis-Suseno, Frans. (1996). Etika Jawa. Jakarta: Gramedia Pustaka Utama

Marina. (2008). Wayang Kulit sebagai media penyebaran agama Islam. Surakarta: UNS.

Miksic, John. (2002). Arsitektur Periode Awal Islam” dalam Indonesian Heritage Volume Arsitektur. Jakarta: Grolier. 
Muhaemin, E., \& Sanusi, I. ((2019). Intoleransi Keagamaan dalam Framing Surat Kabar Kompas. Communicatus: Jurnal Ilmu komunikasi. Vol 3 No. 1.

Nasution. (1988). Metode Penulisan Naturalistik Kualitatif. Bandung: Tarsito.

Notosusanto, Nugroho. (1978). Masalah Penelitian Sejarah Kontemporer. Jakarta: Yayasan Idayu.

PaEni, Muklis. (2009). Sejarah Kebudayaan Indonesia. Jakarta: PT Raja Grafindo Persada.

Palgunadi, Bram. (1978). Tinjauan Tentang Wayang Kulit. Bandung:Bulletin PSTKITB

Poespowardojo, Soerjanto. (1993). Strategi Kebudayaan (Suatu pendekatan Filosofis). Jakarta: PT Gramedia Pustaka Utama.

Qodir, Zuly. (2016). Kaum Muda, Intoleransi, dan Radikalisme Agama. Jurnal Studi Pemuda. Vol. 5 no. 1.

Saefullah, Asep. (2004). Islamisasi di Indonesia, Telaah Seputar Masuknya Islam. Jurnal: Lektur Keagamaan. Depag RI Vol 2 No.1.

Saepudin, Didin. (2006). Proses Islamisasi Penduduk Indonesia dalam Perspektif Sejarah. Jurnal Mimbar Agama dan Budaya: UIN Jakarta Vol.23 No. 3.

Salam, Solochin. (1997). Sekitar Walisanga. Jakarta:Menara Kudus

Sidik, Suyanto. (2012). Membaca Kearifan Lokal dan Islam Jawa.

Sujamto. (1992). Wayang dan Budaya Jawa. Semarang: Effhar dan Dahara Prize

Suparjo. (2008). Islam dan budaya: Strategi Kultural Walisongo dalam Membangun Masyarakat Muslim Indonesia. Jurnal Komunika Vol.2 No.2.

Supatmo. (2017). Perwujudan Estetis Seni Ornamen Masjid Peninggalan Walisanga di Jawa Tengah. Jurnal Imajinasi Vol XI No. 2

Susanti-Sahar, B. M. (1999). Dimensi Renovasi Mesjid Menara Kudus Tahun 19191978: Kajian Aspek Historis. Yogyakarta

Syafi'i dan Sabil Huda, (1987). Sejarah dan Kebudayaan Islam. Bandung: Armico.

Yatim, Badri. (2008). Sejarah Peradaban Islam Dirasah Islamiyyah II. Jakarta:PT Raja Gravindo Persada.

Zed, Mestika. (2004). Metode Penelitian Kepustakaan. Jakarta: Yayasan Obor Indonesia. 